\title{
Isolation and identification of Staphylococcus aureus obtained from cheese samples
}

\section{Elif Bozcal}

Cite this article as:

Bozcal, E. (2020). Isolation and identification of Staphylococus aureus obtained from cheese samples. Food and Health, 6(3), 151-159.

https://doi.org/10.3153/FH20016

Istanbul University, Faculty of Science, Department of Biology, Basic and Industrial Microbiology Section, 34134, Istanbul, Turkey

ORCID IDs of the authors: E.B. 0000-0003-2836-778X

Submitted: 13.11 .2019

Revision requested: 09.02 .2020

Last revision received: 28.02 .2020

Accepted: 29.02 .2020

Published online: 04.05 .2020

Correspondence: Elif BOZCAL

E-mail: elif.bozcal@istanbul.edu.tr

\begin{abstract}
Milk and dairy products including cheese are one of the most significant food commodities in terms of the food industry. However, a contaminated food product could conduce a variety of food borne bacterial infections. Although Staphylococcus aureus is known as normal flora members of the humans, it's often isolated from the community and hospital-acquired infections. Therefore, investigation of Staphylococcus aureus from cheese samples was aimed in this study. A total of nineteen $(\mathrm{n}=19)$ white cheese was collected from various outdoor markets in Istanbul. All cheese samples were evaluated quantitatively. Phenotypic identification tests including Gram staining, oxidase, catalase, mannitol, and DNase were performed. The presumptive Staphylococcus aureus colonies $(\mathrm{n}=47)$ were analyzed by the $16 \mathrm{~S}$ rRNA PCR and sequencing. And the sequences were deposited into the National Center for Biotechnology Information. According to the nucleotide BLAST analysis, a total of 47 Staphylococaceae and Enterococcaceae members including Staphylococcus aureus $(\mathrm{n}=3)$, Staphylococcus carnosus $(\mathrm{n}=1)$, Macrococcus caseolyticus $(\mathrm{n}=1)$, Enterococcus faecalis $(\mathrm{n}=25)$, Enterococcus faecium $(\mathrm{n}=12)$, Enterococcus durans $(\mathrm{n}=4)$, and Enterococcus gallinarum $(\mathrm{n}=1)$ were identified. Regarding methicillin susceptibility testing, two of out of three Staphylococcus aureus were detected as methicillin-resistant.
\end{abstract}

Keywords: Staphylococcus aureus, 16S rRNA, cheese, PCR

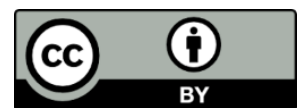

(C) Copyright 2020 by ScientificWebJournals Available online at

http://jfhs.scientificwebjournals.com 


\section{Introduction}

The white cheese is the most consumed cheese type in Turkey and the cheese consumption per capita was determined as 8.7 $\mathrm{kg} /$ person in 2017 and $9.2 \mathrm{~kg}$ in 2020 (Temelli et al.,2006; Ataseven, Z, 2017; www.statista.com) Cheese is such a nourishing food that could provide an environment to the bacteria for growing and multiplication including Salmonella, Escherichia, and Staphylococcus because of the contamination. From the production of cheese to the point of sale, an inadequate sanitization procedure of equipment and utensils lead to contamination of the cheese products and this affects not only food quality but also public health (Donnely, 1990; Aguilar et al., 2016).

Staphylococcus aureus (S. aureus) is known as normal flora member of the human skin, however, some strains of the $S$. aureus is the main reason of the infections and intoxications in terms of consumption of the contaminated milk, dairy products and other foods (Kadiroglu et al., 2014; Bingöl and Toğay, 2017). Staphylococcal food intoxication is a gastrointestinal disease that occurs due to the toxin produced $S$. aureus. When food or ingredients is contaminated by the enterotoxigenic strain of Staphylococcus spp., Staphylococcal food poisoning could be induced on the occasion of Staphylococci growth and enterotoxin production (Hennekinne et al., 2012; https://www.ndhealth.gov/Disease). Moreover, pathogenic strains of $S$. aureus could cause skin lesions, septicaemia, and meningitis in humans and it's responsible for bovine mastitis in animals (Younis et al., 2003; Baran et al., 2017). The transmission of $S$. aureus to dairy products such as milk and cheese could occur via mastitis, mammary glands or animal, skin (Saka and Gulel, 2018). There may be a risk of contamination from personnel and equipment during the production of dairy products. In other words, transmission can be occurred also by animal to animal during milking as well as by the food-handlers, human to food contamination route (Kümmel et al 2016; Monte et al., 2018). Methicillinresistant S. aureus (MRSA) is one of the most significant bacteria in terms of human global health due to the responsible for both community and hospital-acquired infections (Harrison et al., 2014). Moreover, livestock-associated MRSA (LAMRSA) infections originated from livestock such as pigs, goats, and dairy cattle could transmit to the humans who is working in farms and abattoirs where raw meat processed. LA-MRSA could be occurred by handling contaminated meats. Therefore, LA-MRSA could be also the reason for human infections (Cuny et al., 2015).

Although, the isolation of the MRSA from animal and food origin were investigated frequently, the adverse effect of MRSA in dairy products illness is relatively low (Herrera et al., 2016). Hence, identification of $S$. aureus in cheese samples is important for both the food industry and public health. In this study, it was aimed to identify $S$. aureus in white cheese samples sold in outdoor markets in Istanbul.

\section{Materials and Methods}

\section{Sample Collection and Bacteriological Analysis}

A total of nineteen $(n=19)$ white cheese was collected from outdoor markets in Istanbul in April 2018 and September 2019. The color and $\mathrm{pH}$ value of each cheese samples were recorded (Creamy and white, pH:6.8-7.5). The cheese samples were analyzed quantitatively by homogenizing $25 \mathrm{~g}$ cheese and $225 \mathrm{ml}$ peptone water (Peptone: $10 \mathrm{~g} / \mathrm{L}, \mathrm{NaCI}: 5.0$ $\mathrm{g} / \mathrm{L} \mathrm{pH:} \mathrm{7.2 \pm 0.2)} \mathrm{within} \mathrm{24-hour.} \mathrm{The} \mathrm{10-fold} \mathrm{serial} \mathrm{dilutions}$ were spread on Baird-Parker Agar Medium supplemented with Egg Yolk Enrichment (Becton Dickinson). Typical colonies (dark gray to black colonies with clear zones) were selected and counted for further identification analysis followed by the $24-\mathrm{h}$ for $37^{\circ} \mathrm{C}$ incubation. Phenotypic identification tests including Gram staining, oxidase testing of cytochorome oxidase with indicator (tetramethyl-p-phenylenediamine) conversion to the indophenols catalase (A slide drop with 3\% $\mathrm{H}_{2} \mathrm{O}_{2}$ onto the presumptive $S$.aureus isolates on microscope slides), mannitol fermentation (mannitol-fermentation as a carbohydrate source in the presence of phenol red as a $\mathrm{pH}$ indicator to detect mannitol-fermenting Staphylococci), and DNase (DNA hydrolysis test composed of growing microorganism in the DNAse test agar medium that produces Deoxyribonuclease when the DNA is broken down resulting with clear zone and green color fades) were performed. The presumptive (typical colonies) $S$. aureus colonies $(\mathrm{n}=47)$ were taken into consideration for further identification analysis.

\section{Genomic DNA Isolation and 16S rRNA Sequencing}

The genomic DNA isolation of the presumed S. aureus colonies $(n=47)$ was performed by using GeneAll ${ }^{\circledR}$ (South Korea) genomic DNA isolation kit according to the manufacturer's instructions. Isolated genomic DNA samples were stored at $20{ }^{\circ} \mathrm{C}$ until PCR analysis. The 16S rRNA PCR analysis was performed according to the Frank et al. (2008). The 16S rRNA gene were amplified in a $50 \mu 1$ reaction volume including 1xPCR buffer (Maximo, GeneON), $0.2 \mathrm{mM}$ of each dNTPs, $2.5 \mathrm{mM} \mathrm{MgCl}_{2}$, and $0.5 \mu \mathrm{M}$ of each primer (16S rRNA:27F-AGAGTTTGATCCTGGCTCAG and 1492RGGTTACCTTGTTACGACTT) (Suardana, 2014). The PCR reaction was performed as following conditions: 2 min initial denaturation at $95^{\circ} \mathrm{C}, 25$ cycles of denaturation $1 \mathrm{~min}$ at 95 ${ }^{\circ} \mathrm{C}$, annealing at $55^{\circ} \mathrm{C}$ for $1 \mathrm{~min}$, and extension at $72^{\circ} \mathrm{C}$ for 2 min and 10 min final extension at $72^{\circ} \mathrm{C}$. The obtained PCR 
amplicons $(\sim 1465 \mathrm{bp})$ were evaluated by agarose gel electrophoresis $(1.0 \%)$ and screened by a transilluminator implemented in WiseDoc Gel Doc System. The purification of $16 \mathrm{~S}$ rRNA gene amplicons was performed by BMLabosis (Ankara, Turkey) using the ExoSap-IT (Affymetrix) kit. Later on, samples were sent to Macrogen (Amsterdam, The Netherlands) for the unidirectional sequencing via ABI 3730XL automated sequencer (Applied Biosystems, Foster City, CA, USA), and the BigDye Terminator v3.1 Cycle Sequencing Kit (Applied Biosystems). The obtained reads were aligned and trimmed using the SILVA (Quast et al., 2013). All 16S rRNA gene sequences $(n=47)$ were deposited into the NCBI GenBank followed by the nucleotide BLAST analysis (NCBI Accession No: MK791580-MK79194 and MN629248MN629279) (Table 1).

\section{Methicillin susceptibility testing}

In order to detect MRSA identified by $16 \mathrm{~S}$ rRNA sequencing, the agar screening method was performed according to the Brown et al.,2008. Briefly, the density of the $S$. aureus isolates was arranged to the $0.5 \mathrm{McFarland}$ standard. After that, a spot inoculation $(10 \mu \mathrm{l})$ of $S$. aureus into the Mueller Hinton Agar medium (HiMedia) including 4\% NaCI (Conda) and 6 $\mathrm{mg} / \mathrm{L}$ methicillin (Sigma) was performed. Plates were incubated at $37^{\circ} \mathrm{C}$ for 24 -hour. The growth of any single colonies on methicillin plate is evaluated as resistant (Brown and Yates,1986; Brown et al., 2008).

\section{Results and Discussion}

The preparation and consumption of the cheese products with unhygienic conditions could lead to the proliferation of the $S$. aureus in cheese and it can be posing a high risk for public health. Detection, enumeration, and identification of the $S$. aureus especially coagulase positive and methicillin - resistant strains are significant. While coagulase-positive $S$. $a u$ reus strains can produce an enterotoxin, coagulase-negative isolates could able to produce enterotoxin (Nunes et al., 2015; Yildirim et al., 2019). Therefore, coagulase - negative $S$. aureus strains should be taken into consideration. In Turkey, there have been several studies that indicate the prevalence and presence of $S$. aureus strains in various cheese samples. The detection percentage were ranging from $20.2 \%$ to $92 \%$
(Yücel and Anıl, 20011; Gökmen et al., 2013; Bingöl and Togay, 2017). The high percentage of the detection could indicate health risk in the cheese samples which has been consumed widely in Turkey. In our study, out of 19 white cheese samples, three $(\mathrm{n}=3)(15 \%) S$. aureus were identified and two of them were reported as methicillin-resistant (Table 1). Similarly, the detection percentage of MRSA is not high in Turkey. For example, Saka and Gulel (2018) reported MRSA was $9 \%$. In another study, the detection percentage was 1.70 $\%$, even though MRSA was investigated from 175 milk and dairy products (Ektik et al., 2017). Nevertheless, these data could show that a serious health problem.

All cheese samples were evaluated quantitatively in this study. The enumeration results were $1.6 \times 10^{4} \mathrm{CFU} / \mathrm{g}\left(\mathrm{CE} \_1\right)$, 9.77x10 $\mathrm{CFU} / \mathrm{g}\left(\mathrm{CE} \_2\right), 3.1 \times 10^{3} \mathrm{CFU} / \mathrm{g}$ (CE_3), $1.51 \times 10^{6}$

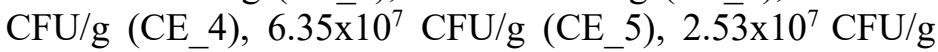

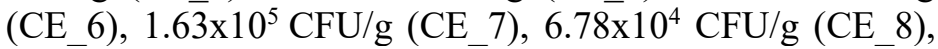
$8.05 \times 10^{5} \mathrm{CFU} / \mathrm{g}$ (CE_9), $1.68 \times 10^{3} \mathrm{CFU} / \mathrm{g}\left(\mathrm{CE} \_10\right), 1.27 \times 10^{3}$ $\mathrm{CFU} / \mathrm{g}\left(\mathrm{CE} \_11\right), 3.40 \times 10^{4} \mathrm{CFU} / \mathrm{g}\left(\mathrm{CE} \_12\right), 2.51 \times 10^{7} \mathrm{CFU} / \mathrm{g}$ (CE_13), $1.40 \times 10^{7} \quad \mathrm{CFU} / \mathrm{g} \quad\left(\mathrm{CE} \_14\right), 2.34 \times 10^{7} \quad \mathrm{CFU} / \mathrm{g}$ (CE_15), 2.18x0 $0^{7} \mathrm{CFU} / \mathrm{g}$ (CE_16), $1.67 \times 0^{6} \mathrm{CFU} / \mathrm{g}$ (CE_17), $1.70 \times 0^{6} \mathrm{CFU} / \mathrm{g}\left(\mathrm{CE} \_18\right), 1.30 \times 10^{5} \mathrm{CFU} / \mathrm{g}$ (CE_20). The microbiological criteria in terms of the presence of coagulasepositive Staphylococcus species in cheese products established by the Food and Drug Administration (FDA) is $10^{2}-10^{3}$ $\mathrm{CFU} / \mathrm{g}$ was acceptable (https://www.fda.gov/media/74723/download). At the same time, Turkish Food Codex Microbiological Criteria takes into consideration the same reliability limits $\left(10^{2}-10^{3} \mathrm{CFU} / \mathrm{g}\right)$ in cheese products (Turkish Official Journal, 2011) However, the presence of Staphylococcus species more than $10^{4} \mathrm{CFU} / \mathrm{gr}$ in cheese product considered to be risky according to the compliance Policy Guide of FDA (Kadiroğlu et al., 2014; https://www.fda.gov/media/74723/download). In this study, 15 out of the 19 cheese samples included more than $10^{4} \mathrm{CFU} / \mathrm{g}$ presumed Staphylococcus species could be considered as hazardous for public health. The number of Staphylococcus (CFU) or concentration of enterotoxin can be shown a determining factor of risk situation. In other words, the enterotoxigenic strains of Staphylococcus is necessary to grow before the toxin production at detectable levels. Thereby, to cause an infection, a high dose of Staphylococcus is required (Food Safety Authority of Ireland 2011; Pollitt et al., 2018). 
Table 1. Phenotypic characteristics and $16 \mathrm{~S}$ rRNA genotypic identification of $S$. aureus, S. carnosus, E. faecalis, and M. caseolyticus, E. faecium, E.durans, and E. gallinarum isolates obtained from cheese samples

\begin{tabular}{|c|c|c|c|c|c|c|c|c|c|}
\hline No & ID & 16S rRNA & $\begin{array}{c}\text { GenBank } \\
\text { Accession No }\end{array}$ & $\begin{array}{c}\text { Gram_Reaction } \\
\text { morphology }\end{array}$ & $\mathbf{O}$ & C & $\mathbf{M}$ & D & $\begin{array}{l}\text { Methicil- } \\
\operatorname{lin}(\mathbf{R} / \mathbf{S})\end{array}$ \\
\hline CE_2 & CE_2 & $\begin{array}{c}\text { Staphylococcus carnosus } \\
\text { CE_2 }\end{array}$ & MK791585 & $(+)$-coccus & $(-)$ & $(+)$ & $(+)$ & $(+)$ & \\
\hline CE_3 & CE_3_2 & $\begin{array}{c}\text { Enterococcus faecalis } \\
\text { CE_3_2 }\end{array}$ & MK791587 & $(+)$-coccus & $(-)$ & $(+)$ & $(+)$ & $(-)$ & \\
\hline CE_1 & CE_1_1 & $\begin{array}{c}\text { Enterococcus faecalis } \\
\text { CE_1_1 }\end{array}$ & MK791580 & $(+)$-coccus & $(-)$ & $(+)$ & $(+)$ & $(+)$ & \\
\hline CE_1 & CE_1_2 & $\begin{array}{c}\text { Enterococcus faecalis } \\
\text { CE_1_2 }\end{array}$ & MK791581 & $(+)$-coccus & $(-)$ & $(-)$ & $(+)$ & $(+)$ & \\
\hline CE_1 & CE_1_3 & $\begin{array}{c}\text { Enterococcus faecalis } \\
\text { CE_1_3 }\end{array}$ & MK791582 & $(+)$-coccus & $(-)$ & $(+/-)$ & $(+)$ & $(-)$ & \\
\hline CE_1 & CE_1_4 & $\begin{array}{c}\text { Enterococcus faecalis } \\
\text { CE_1_4 }\end{array}$ & MK791583 & $(+)$-coccus & $(-)$ & $(+/-)$ & $(+)$ & $(-)$ & \\
\hline CE_1 & CE_1_5 & $\begin{array}{c}\text { Enterococcus faecalis } \\
\text { CE_1_5 }\end{array}$ & MK791584 & $(+)$-coccus & $(-)$ & $(+/-)$ & $(+)$ & $(-)$ & \\
\hline CE_4 & CE_4_2 & $\begin{array}{c}\text { Enterococcus faecalis } \\
\text { CE_4_2 }\end{array}$ & MK791592 & $(+)$-coccus & $(-)$ & $(+)$ & $(+)$ & $(+)$ & \\
\hline CE_4 & CE_4_3 & $\begin{array}{c}\text { Enterococcus faecalis } \\
\text { CE_4_3 }\end{array}$ & MK791593 & $(+)$-coccus & $(-)$ & $(+/-)$ & $(+)$ & $(-)$ & \\
\hline CE_4 & CE_4_4 & $\begin{array}{c}\text { Enterococcus faecalis } \\
\text { CE_4_4 }\end{array}$ & MK791594 & $(+)$-coccus & $(-)$ & $(+/-)$ & $(+)$ & $(+)$ & \\
\hline CE_3 & CE_3_3 & $\begin{array}{c}\text { Enterococcus faecalis } \\
\text { CE_3_3 }\end{array}$ & MK791588 & $(+)$-coccus & $(-)$ & $(+)$ & $(+)$ & $(+)$ & \\
\hline CE_3 & CE_3_4 & $\begin{array}{l}\text { Staphylococcus aureus } \\
\text { CE_3_4 }\end{array}$ & MK791589 & $(+)$-coccus & $(-)$ & $(+)$ & $(-)$ & $(-)$ & $\mathrm{S}$ \\
\hline CE_3 & CE_3_5 & $\begin{array}{c}\text { Enterococcus faecalis } \\
\text { CE_3_5 }\end{array}$ & MK791590 & $(+)$-coccus & $(-)$ & $(+)$ & $(+)$ & $(+)$ & \\
\hline CE_4 & CE_4_1 & $\begin{array}{c}\text { Enterococcus faecalis } \\
\text { CE_4_1 }\end{array}$ & MK791591 & $(+)$-coccus & $(-)$ & $(+)$ & $(+)$ & $(-)$ & \\
\hline CE_3 & CE_3_1 & $\begin{array}{c}\text { Macrococcus caseolyti- } \\
\text { cus CE_3_1 }\end{array}$ & MK791586 & $(+)$-coccus & $(-)$ & $(+)$ & $(-)$ & $(-)$ & \\
\hline CE_5 & CE_5_1 & $\begin{array}{c}\text { Enterococcus faecium } \\
\text { CE_5_1 }\end{array}$ & MN629248 & $(+)$-coccus & $(-)$ & $(-)$ & $(-)$ & $(-)$ & \\
\hline CE_5 & CE_5_3 & $\begin{array}{l}\text { Enterococcus durans } \\
\text { CE_5_3 }\end{array}$ & MN629249 & $(+)$-coccus & $(-)$ & $(-)$ & $(-)$ & $(-)$ & \\
\hline CE_5 & CE_5_4 & $\begin{array}{c}\text { Enterococcus faecium } \\
\text { CE_5_4 }\end{array}$ & MN629250 & $(+)$-coccus & $(+)$ & $(-)$ & $(-)$ & $(-)$ & \\
\hline CE_6 & CE_6_1 & $\begin{array}{c}\text { Enterococcus faecium } \\
\text { CE_6_1 }\end{array}$ & MN629251 & $(+)$-coccus & $(-)$ & $(-)$ & $(-)$ & $(-)$ & \\
\hline CE_6 & CE_6_2 & $\begin{array}{c}\text { Enterococcus faecium } \\
\text { CE_6_2 }\end{array}$ & MN629252 & $(+)$-coccus & $(-)$ & $(-)$ & $(+)$ & $(-)$ & \\
\hline CE_6 & CE_6_3 & $\begin{array}{c}\text { Enterococcus faecium } \\
\text { CE_6_3 }\end{array}$ & MN629253 & $(+)$-coccus & $(+)$ & $(-)$ & $(+)$ & $(-)$ & \\
\hline CE_7 & CE_7_2 & $\begin{array}{c}\text { Enterococcus faecium } \\
\text { CE_7_2 }\end{array}$ & MN629254 & $(+)$-coccus & $(-)$ & $(-)$ & $(-)$ & $(-)$ & \\
\hline CE_8 & CE_8_1 & $\begin{array}{c}\text { Enterococcus faecium } \\
\text { CE_8_1 }\end{array}$ & MN629255 & $(+)$-coccus & $(+)$ & $(-)$ & $(-)$ & $(-)$ & \\
\hline
\end{tabular}




\begin{tabular}{|c|c|c|c|c|c|c|c|c|c|}
\hline CE_ 8 & CE_8_2 & $\begin{array}{c}\text { Enterococcus durans } \\
\text { CE_8_2 }\end{array}$ & MN629256 & $(+)$-coccus & $(-)$ & $(-)$ & $(-)$ & $(-)$ & \\
\hline CE_8 & CE_8_3 & $\begin{array}{c}\text { Enterococcus faecium } \\
\text { CE_8_3 }\end{array}$ & MN629257 & $(+)$-coccus & $(-)$ & $(-)$ & $(-)$ & $(-)$ & \\
\hline CE_9 & CE_9_2 & $\begin{array}{c}\text { Enterococcus faecium } \\
\text { CE_9_2 }\end{array}$ & MN629258 & $(+)$-coccus & $(+)$ & $(-)$ & $(-)$ & $(-)$ & \\
\hline CE_10 & CE_10_1 & $\begin{array}{c}\text { Enterococcus faecium } \\
\text { CE_10_1 }\end{array}$ & MN629259 & $(+)$-coccus & $(-)$ & $(-)$ & $(-)$ & $(-)$ & \\
\hline CE_10 & CE_10_2 & $\begin{array}{c}\text { Enterococcus faecium } \\
\text { CE_10_2 }\end{array}$ & MN629260 & $(+)$-coccus & $(-)$ & $(-)$ & $(-)$ & $(+)$ & \\
\hline CE_11 & CE_11_1 & $\begin{array}{c}\text { Enterococcus faecium } \\
\text { CE_11_1 }\end{array}$ & MN629261 & $(+)$-coccus & $(+)$ & $(-)$ & $(-)$ & $(-)$ & \\
\hline CE_11 & CE_11_2 & $\begin{array}{l}\text { Enterococcus durans } \\
\text { CE_11_2 }\end{array}$ & MN629262 & $(+)$-coccus & $(-)$ & $(-)$ & $(-)$ & $(-)$ & \\
\hline CE_11 & CE_11_3 & $\begin{array}{l}\text { Enterococcus durans } \\
\text { CE_11_3 }\end{array}$ & MN629263 & $(+)$-coccus & $(+)$ & $(-)$ & $(-)$ & $(-)$ & \\
\hline CE_12 & CE_12_2 & $\begin{array}{l}\text { Enterococcus faecalis } \\
\text { CE_12_2 }\end{array}$ & MN629264 & $(+)$-coccus & $(-)$ & $(-)$ & $(+)$ & $(-)$ & \\
\hline CE_12 & CE_12_3 & $\begin{array}{c}\text { Enterococcus faecalis } \\
\text { CE_12_3 }\end{array}$ & MN629265 & $(+)$-coccus & $(-)$ & $(-)$ & $(+)$ & $(-)$ & \\
\hline CE_12 & CE_12_4 & $\begin{array}{l}\text { Staphylococcus aureus } \\
\text { CE_12_4 }\end{array}$ & MN629266 & $(+)$-coccus & $(-)$ & $(+)$ & $(+)$ & $(+)$ & $\mathrm{R}$ \\
\hline CE_13 & CE_13_1 & $\begin{array}{l}\text { Staphylococcus aureus } \\
\text { CE_13_1 }\end{array}$ & MN629267 & $(+)$-coccus & $(-)$ & $(+)$ & $(+)$ & $(+)$ & $\mathrm{R}$ \\
\hline CE_14 & CE_14_2 & $\begin{array}{c}\text { Enterococcus faecalis } \\
\text { CE_14_2 }\end{array}$ & MN629268 & $(+)$-coccus & $(-)$ & $(-)$ & $(+)$ & $(+)$ & \\
\hline CE_14 & CE_14_3 & $\begin{array}{l}\text { Enterococcus faecalis } \\
\text { CE_14_3 }\end{array}$ & MN629269 & $(+)$-coccus & $(+)$ & $(-)$ & $(+)$ & $(+)$ & \\
\hline CE_15 & CE_15_1 & $\begin{array}{l}\text { Enterococcus faecalis } \\
\text { CE_15_1 }\end{array}$ & MN629270 & $(+)$-coccus & $(+)$ & $(-)$ & $(+)$ & $(+)$ & \\
\hline CE_15 & CE_15_3 & $\begin{array}{c}\text { Enterococcus faecalis } \\
\text { CE_15_3 }\end{array}$ & MN629271 & $(+)$-coccus & $(-)$ & $(-)$ & $(+)$ & $(+)$ & \\
\hline CE_16 & CE_16_2 & $\begin{array}{c}\text { Enterococcus faecalis } \\
\text { CE_16_2 }\end{array}$ & MN629272 & $(+)$-coccus & $(-)$ & $(-)$ & $(+)$ & $(+)$ & \\
\hline CE_17 & CE_17_1 & $\begin{array}{l}\text { Enterococcus gallinarum } \\
\text { CE_17_1 }\end{array}$ & MN629273 & $(+)$-coccus & $(-)$ & $(-)$ & $(+)$ & $(+)$ & \\
\hline CE_18 & CE_18_1 & $\begin{array}{c}\text { Enterococcus faecalis } \\
\text { CE_18_1 }\end{array}$ & MN629274 & $(+)$-coccus & $(-)$ & $(-)$ & $(+)$ & $(+)$ & \\
\hline CE_18 & CE_18_2 & $\begin{array}{c}\text { Enterococcus faecalis } \\
\text { CE_18_2 }\end{array}$ & MN629275 & $(+)$-coccus & $(+)$ & $(-)$ & $(+)$ & $(+)$ & \\
\hline CE_18 & CE_18_3 & $\begin{array}{c}\text { Enterococcus faecalis } \\
\text { CE_18_3 }\end{array}$ & MN629276 & $(+)$-coccus & $(+)$ & $(-)$ & $(+)$ & $(+)$ & \\
\hline CE_20 & CE_20_1 & $\begin{array}{c}\text { Enterococcus faecalis } \\
\text { CE_20_1 }\end{array}$ & MN629277 & $(+)$-coccus & $(-)$ & $(-)$ & $(+)$ & $(-)$ & \\
\hline CE_20 & CE_20_3 & $\begin{array}{l}\text { Enterococcus faecalis } \\
\text { CE_20_3 }\end{array}$ & MN629278 & $(+)$-coccus & $(-)$ & $(-)$ & $(+)$ & $(-)$ & \\
\hline CE_20 & CE_20_4 & $\begin{array}{c}\text { Enterococcus faecalis } \\
\text { CE_20_4 }\end{array}$ & MN629279 & $(+)$-coccus & $(-)$ & $(-)$ & $(+)$ & $(-)$ & \\
\hline
\end{tabular}


Presumptive $S$. aureus isolates (isolate IDs: CE_12_4 and CE_13_1) were compatible with the phenotypic identification tests including oxidase, catalase, mannitol fermentation, and Dnase. However, presumptive $S$. aureus isolate (ID: CE_3_4) was mannitol fermentation and DNAse tests were negative (Table 1). Although phenotypic tests for the isolate CE 3 4 were not coherent, some of strains of the $S$. aureus could show a negative reaction for the DNase and mannitol fermentation tests (Kateete et al., 2010). According to the $16 \mathrm{~S}$ rRNA identification results, presumptive isolates (IDs: CE_13_1, CE_12_4 and CE_3_4) were identified as $S$. aureus. In accordance with phenotypic identification tests for the isolates including $\mathrm{CE} \_2, \mathrm{CE} \_1$ 1, CE_4_2, CE_4_4, CE_3_3, and CE 3_5 were considered as S. aureus. However, the 16S rRNA identification test showed that these isolates were identified as CE_2 (S. carnosus), CE_1_1 (E. faecalis), CE_4_2 (E. faecalis), CE_4_4 (E. faecalis, CE_3_3 (E.faecalis), and CE_3_5 (E.faecalis). Therefore, our results showed that some of the phenotypic identification tests did not correspond to the genotypic identification test. Considering the phenotypic results in Table 1, it was seen that only 47 of the phenotypic test results did not indicate $S$. aureus. On occasion, phenotypic tests can be variable under some conditions. For instance, E. faecalis is catalase- positive under the acquisition of heme however, E. faecalis strains are catalase negative (Frankkenberg et al., 2002). The 16S rRNA analysis showed that the other Staphylococaceae members including Staphylococcus carnosus $(\mathrm{n}=1)$, and Macrococcus caseolyticus $(\mathrm{n}=1)$ were reported in this study. Moreover, Enterococcus faecalis $(\mathrm{n}=25)$ Enterococcus faecium $(n=12)$, Enterococcus durans $(n=4)$, and Enterococcus gallinarum $(n=1)$ belonging to the Enterococcaceae family was reported in this study (Table 1). Although E. gallinarum was reported from clinical samples in Turkey (Özseven et al., 2011), E. gallinarum can be isolated during cheese making and ripening procedure. In Italy, E. gallinarum was reported a low abundance in artisanal Italian goat's cheese during ripening procedure (Suzzi et al., 2011).

S. carnosus is generally isolated from meat products or fish and it's known as meat starter culture (Bückle et al., 2017). Similarly, in Turkey, S. carnosus was reported from Turkish fermented sausage (Nazli, 1998). Another study that was carried on in France, S. carnosus was detected only in dry sausage samples (Coton et al., 2010). The detection of $S$. carnosus in our study could show the contamination of cheese samples. M. caseolyticus was also identified in various dairy and meat food sources related to flavor development (Mazhar et al., 2018). Besides, M. caseolyticus can be isolated from bovine milk, chicken, and humans. In Switzerland, M. caseolyticus was isolated from bovine mastitis milk (Schvendener et al., 2017). However, to best our knowledge, M. caseolyticus has not been detected from white cheese samples in Turkey before. As distinct from S. carnosus and M. caseolyticus, E. faecalis is known as a flora member of the gastrointestinal tract in humans and animals (Abdeen et al., 2016). However, the presence of E. faecalis in food sources such as cheese could show fecal contamination and/or inadequate hygienic measures in cheese samples. Moreover, the transmission of E. faecalis to the human by consumption of dairy products could cause various infections (Anderson et al., 2016). Similarly, various antibiotic - resistant Enterococci such as E. faecium has been reported from nosocomial-acquired patients (Sanders et al., 2010). Along with the harmful effects of Enterococci, these species are also known to have probiotic potential. Because Enterococci has a tolerance to the salts and acids thereby, Enterococci could adapt to various foods and could involve the fermentation process of cheese. (Hanchi et al., 2018). And another striking feature of Enterococci including E. faecalis, E. faecium, and E. durans has lipolytic activity and production of aromatic compounds (Amaral et al., 2016). In Turkey, E. faecium has been used for cheese production as a starter culture. And they were concluded that E. faecium FAIR-E 198 could be used as a starter culture (Göncüoglu et al., 2009).

\section{Conclusion}

In conclusion, S. aureus, E. faecalis, E. faecium, E. durans, E. gallinarum, $S$. carnosus, and $M$. caseolyticus were identified by phenotypic and genotypic identification methodologies. Phenotypic identification tests results should be validated by genotypic identification tests. The detection of MRSA in our study could show the significance of the methicillin resistance in cheese samples for public health. To prevent the transmission of $S$. aureus to cheese products, hygiene and sanitation precautions should be taken during production and sales of the cheese. Also, critical control points should be determined. According to our data, the presence of $S$. aureus and Enterococci in cheese products could give an opinion about transmission strategies of these bacteria needed to be studied.

\section{Compliance with Ethical Standard}

Conflict of interests: The authors declare that for this article they have no actual, potential or perceived the conflict of interests.

Ethics committee approval: Author declare that this study does not include any experiments with human or animal subjects.

\section{Funding disclosure: -}

Acknowledgments: This study was partly presented as an oral presentation at the $2^{\text {nd }}$ International Eurasian Conference on Biological and Chemical Sciences (EurasianBioChem 2019) Ankara- 
Turkey, 28-29 June 2019). The Author used the facilities of BM Labosis (Ankara, Turkey) for the Sanger Sequencing.

\section{References}

Abdeen, E.E., Hussein, H., Hussan, Z., Abdella., W. (2016). Genotyping and virulence genes of Enterococcus faecalis Isolated from Kareish cheese and minced meat in Egypt. Research Journal of Microbiology, 11, 133-138.

https://doi.org/10.3923/jm.2016.133.138

Aguilar, C.E.G.A., Junior, O.D.R., Vidal, A.M.C.V., Ribeiro, L.F, Rossi, G.A.M. (2016). Microbial quality of industrial and retail market grated parmesan cheese in the State of São Paulo, Brazil. Food Technology, 46(12), 2257-2263. https://doi.org/10.1590/0103-8478cr20160334

Amaral, M.F.A., Silva, L.F., Casarotti, S.N., Nascimento, L.C.S., Penna, A.L.B. (2017). Enterococcus faecium and Enterococcus durans isolated from cheese: Survival in the presence of medications under simulated gastrointestinal conditions and adhesion properties. Journal of Dairy Science, 100(2), 933-949.

https://doi.org/10.3168/jds.2016-11513

Anderson, A.C, Jonas, D., Huber, I., Karygianni, L.,Wölber, J., Hellwig, E., Arweiler, N., Vach, K., Wittmer, A., Al-Ahmad, A. (2016). Enterococcus faecalis from food, clinical specimens, and oral sites: prevalence of virulence factors in association with biofilm formation. Frontiers in Microbiology, 6, 1534.

https://doi.org/10.3389/fmicb.2015.01534

Ataseven, Y.A. (2017). Durum ve tahmin. Süt ve süt ürünleri. Tarımsal Ekonomi ve Politika Geliştirme Enstitüsü, 305, ISBN: 978-605-2207-17-8.

Baran, A., Erdogan, A., Turgut, T., Adıgüzel, M. (2017). A review on the presence of Staphylococcus aureus in cheese. Turkish Journal of Nature and Science, (6)2, 100-105.

Bingöl, K.K, Toğay, S.Ö. (2017). Enterotoxin production potential and methicillin resistance of Staphylococcus aureus strains isolated from Urfa Cheeses. Akademik Glda, 15(1), 29-35.

https://doi.org/10.24323/akademik-gida.305772

Brown, D.F.J, Edwards, D.I, Hawkey, P.M., Morrison, D., Ridgway, G.L., Towner, K.J. (2008). Guidelines for the laboratory diagnosis and susceptibility testing of methicillin- resistant Staphylococcus aureus (MRSA). Journal Antimicrobial Chemotherapy, 56, 1000-1018.

https://doi.org/10.1093/jac/dki372

Brown, D.F.J, Yates, V.S. (1986). Methicillin susceptibility testing of Staphylococcus aureus on media containing five percent sodium chloride. European Journal of Clinical Microbiology, 5(6), 726-728.

https://doi.org/10.1007/BF02013313

Bückle, A., Kranz, M., Schmidt, H., Weiss, A. (2017). Genetic diversity and population structure of food-borne Staphylococcus carnosus strains. Systematic and Applied Microbiology, 40, 34-41.

https://doi.org/10.1016/j.syapm.2016.11.005

Coton, E., Desmonts, M. H., Leroy, S., Coton, M., Jamet, E., Christieans, S., Donnio, P.Y., Lebert, I., Talon, R. (2010). Biodiversity of coagulase-negative staphylococci in French cheeses, dry fermented sausages, processing environments and clinical samples. International Journal of Food Microbiology 137, 221-229.

https://doi.org/10.1016/j.ijfoodmicro.2009.11.023

Cuny, C., Wieler, L.H., Witte, W. (2015). Livestock-Associated MRSA: The Impact on Humans. Antibiotics, 4, 521543.

https://doi.org/10.3390/antibiotics4040521

Donnely, C.W. (1990). Concerns of microbial pathogens in association with dairy foods. Journal of Dairy Science, 73, 1656-1661.

https://doi.org/10.3168/jds.S0022-0302(90)78838-8

Ektik, N., Gökmen, M., Çibik, R. (2017). The prevalence and antibiotic resistance of methicillin-resistant Staphylococcus aureus (MRSA) in milk and dairy products in Balikesir, Turkey. Journal of the Hellenic Veterinary Medical Society, 68(4), 613-620.

https://doi.org/10.12681/jhvms.16062

Food and Drug Administration Compliance Program

Guidance Manual https://www.fda.gov/me-

dia/74723/download (Accessed at 03.05.2019).

Food Safety Authority of Ireland. (2011). Staphylococcus aureus. Microbial Fact Sheet Series, 1, 1-5.

Frank, J.A, Reich, C.I, Sharma, S., Weisbaum, J.S, Wilson, B.A, Olsen, G.J. (2008). Critical evaluation of two primers commonly used for amplification of bacterial $16 \mathrm{~S}$ rRNA 
genes. Applied and Environmental Microbiology, 74, 24612470.

https://doi.org/10.1128/AEM.02272-07

Frankenberg, L., Brugna, M., Hederstedt, L. (2002). Enterococcus faecalis Heme-dependent catalase. Journal of Bacteriology, 184, 6351-6356.

https://doi.org/10.1128/JB.184.22.6351-6356.2002

Gökmen, N., Gürbüz, Ü., Torlak, E., İnal, M. (2013). Identification of Staphylococcus spp. isolated in different production stages of white cheese and detection of enterotoxin. Kocatepe Veterinary Journal, 6(2), 7-11.

https://doi.org/10.5578/kvj.6145

Göncüoğlu, M., Ormancı, F.S.B., Doğru, A.K. (2009). Beyaz peynir üretiminde Enterococcus faecium'un starter kültür olarak kullanılması, Ankara Üniversitesi Veteriner Fakültesi Dergisi, 56, 249-254.

https://doi.org/10.1501/Vetfak_0000002290

Hanchi, H., Mottawea, W., Sebei, K., Hammami, R. (2018). The Genus Enterococcus: Between probiotic potential and safety concerns-An Update. Frontiers in Microbiology, 9, 1791.

https://doi.org/10.3389/fmicb.2018.01791

Harrison, E.M., Weinert, L.A., Holden, M.T.G., Welch, J.J, Wilson, K, Morgan F.J.E., Harris S.R., Loeffler, A., Boag, A.K., Peacock, S.J., Paterson, G.K, Waller, A.S., Parkhill, J., Holmes, M.A. (2014). A shared population of epidemic methicillin-resistant Staphylococcus aureus 15 circulates in humans and companion animals. Molecular Biology, 5(3), 00985-13.

https://doi.org/10.1128/mBio.00985-13

Hennekinne, J.A., De Buyser, M.L., Dragacci, S. (2012). Staphylococcus aureus and its food poisoning toxins: characterization and outbreak investigation. FEMS Microbiology Reviews 36, 815-836.

https://doi.org/10.1111/j.1574-6976.2011.00311.x

Herrera, F.C., Garcia-Lopez, M., Santos, J.A. (2016). Short communication: Characterization of methicillin-resistant Staphylococcus aureus isolated from raw milk fresh cheese in Colombia, Journal of Dairy Science, 99 (10), 78727876.

https://doi.org/10.3168/jds.2016-11322

https://www.statista.com/outlook/40010400/113/cheese/turkey (Accessed at 13.02.2020).
Kadiroğlu, P., Korel, F., Ceylan, C. (2014). Quantification of Staphylococcus aureus in white cheese by the improved DNA extraction strategy combined with TaqMan and LNA probe-based qPCR. Journal of Microbiological Methods, 105, 92-97.

https://doi.org/10.1016/j.mimet.2014.06.022

Kateete,D.P., Kimanil, C.N., Fred A Katabazi, F.A., Okeng, A., Okee, M.S.,Nanteza, A., Moses Joloba, M.L., Najjuka, F.C. (2010). Identification of Staphylococcus aureus: dNaseand mannitol salt agar improve the efficiency of the tube coagulase test. Annals of Clinical Microbiology and Antimicrobials, 9(23), 1-7.

https://doi.org/10.1186/1476-0711-9-23

Kümmel, J., Stessl, B., Gonano, M., Walcher,G., Bereuter,O., Fricker, M., Grunert, T., Wagner, M., EhlingSchulz, M.(2016).Staphylococcus aureus entrance into the dairy chain: tracking S.aureus from Dairy Cow to Cheese. Frontiers in Microbiology, 7, 1603.

https://doi.org/10.3389/fmicb.2016.01603

Mazhar, S., Hill, C., McAuliffe, O. (2018). A rapid PCRbased method to discriminate Macrococcus caseolyticus and Macrococcus canis from closely-related Staphylococcus species based on the ctaC gene sequence. Journal of Microbiological Methods, 152, 36-38.

https://doi.org/10.1016/j.mimet.2018.07.008

Monte, D.F.M., Júnior,W.D., Abley, M., Gebreyes, W.A., De Oliveira, C. J. B., Júnior, Melanie, Abley, W.D. L., Wondwossen, A.G., De Oliveira, C.J.B. (2018). Antimicrobial resistance and genotypic relatedness of environmental Staphylococci in semi-extensive dairy farms.Veterinary and Animal Science, 6, 103-106.

https://doi.org/10.1016/j.vas.2018.07.007

Nazli, B. (1998). Researches on the ripening of turkish fermented sausage using a local starter culture combination.Turkish Journal of Veterinary and Animal Sciences, 22, 393-397.

Nunes, R.C.S., Aquila, E.M.D., Paschoalin, W.M.F. (2015). Safety evaluation of the coagulase-negative Staphylococci microbiota of salami: superantigenic toxin production and antimicrobial resistance. BioMed Research International, 483548, 1-17.

https://doi.org/10.1155/2015/483548 
Özseven, A.G., Çetin, E.S., Arıdoğan, B.C., Çiftçi, E., Özseven, L. (2011). Antimicrobial Susceptibility of Enterococci Isolated from Various Clinical Specimens, Ankem Dergisi, 25(4), 256-262.

https://doi.org/10.5222/ankem.2011.256

Pollitt, E.J.G., Szkuta, P.T., Burns, N., Foster S.J. (2018). Staphylococcus aureus infection dynamics. PLoS Pathogens, 14(6), e1007112.

https://doi.org/10.1371/journal.ppat.1007112

Quast, C., Pruesse, E., Yil-

maz, P., Gerken J., Schweer, T., Yarza, P., Peplies, J., Gl ockner, F.O. (2013). The SILVA ribosomal RNA gene database project: Improved data processing and web-based tools. Nucleic acid Research, 4, 590-596.

https://doi.org/10.1093/nar/gks1219

Saka, E., Gulel, G.T. (2018). detection of enterotoxin genes and methicillin-resistance in Staphylococcus aureus isolated from water buffalo milk and dairy products, Journal of Food Science, 83(6), 1716-1722.

https://doi.org/10.1111/1750-3841.14172

Sanders, M.E., Akkermans, L.M.A., Haller, D., Hammerman, C., Heimbach, J.T., Hörmannsperger, G., Huys, G. (2010). Safety assessment of probiotics for human use. Gut Microbes, 1,164-185.

https://doi.org/10.4161/gmic.1.3.12127

Schwendener, S. Cotting, K., Perreten, V. (2017). Novel methicillin resistance gene mecD in clinical Macrococcus caseolyticus strains from bovine and canine sources. Scientific Reports, 7, 43797.

https://doi.org/10.1038/srep43797

Staphylococcal food intoxication. Division of disease control (2016). https://www.ndhealth.gov/Disease/Documents/faqs/staph_food_intoxication.pdf (Accessed at 14.02.2019).
Suardana, I.W. (2014). Analysis of nucleotide sequences of the 16S rRNA gene of novel Escherichia coli Strains isolated from feces of human and Bali Cattle. Journal of Nucleic Acids, 475754, 1-7.

https://doi.org/10.1155/2014/475754

Suzzi G., Caruso M., Gardini F., Lombardi A., Vannini L., Guerzoni M. E., Andrighetto, C., Lanorte, M.T. (2000). A survey of the enterococci isolated from an artisanal Italian goat's cheese (Semicotto Caprino). Journal of Applied Microbiology, 89(2), 267-274.

https://doi.org/10.1046/j.1365-2672.2000.01120.x

Temelli, S., Anar, S., Sen, C., Akyuva, P. (2006). Determination of microbiological contamination sources during Turkish white cheese production. Food Control, 17, 856-861. https://doi.org/10.1016/j.foodcont.2005.05.012

Turkish Food Codex Microbiological Criteria, Official journal (29 December 2011), General Directorate of Prime Ministry Legislation Development and Publication, 28157.

Yildirim, T., Sadati, F., Kocaman, B., Sirieken, B. (2019). Staphylococcus aureus and Staphylococcal enterotoxin detection in raw milk and cheese origin coagulase positive isolates. International Journal of Science Letters, (1), 30-41.

Younis, A., Krifucks, O., Heller, E.D., Samra, Z., Glickman, A., Saran Leitner, G. (2003). Staphylococcus aureus exosecretions and bovine mastitis. Journal of Veterinary Medicine, 50(1), 1-7.

https://doi.org/10.1046/j.1439-0450.2003.00613.x

Yücel, N., Anıl, Y. (2011). Identification and antimicrobial susceptibility of Staphylococcus aureus and coagulase negative staphylococci isolated from raw milk and cheese samples. Turk Hijyen ve Deneysel Biyoloji Dergisi, 68(2), 73-78. https://doi.org/10.5505/TurkHijyen.2011.58070 